\title{
Cytophagic histiocytic panniculitis: is it a macrophage activation syndrome in situ?
}

\author{
B Bader-Meunier ${ }^{1 *}$, S Fraitag ${ }^{2}$, CEl Janssen ${ }^{3}, G$ de Saint Basile ${ }^{4}$, K Brochard $^{5}$, N Brousse $^{2}$, C Bodemer $^{6}$, C Wouters $^{7}$ \\ From 18th Pediatric Rheumatology European Society (PReS) Congress \\ Bruges, Belgium. 14-18 September 2011
}

\section{Background}

Cytophagic histiocytic panniculitis (CHP) is a rare lobular panniculitis, characterized by subcutaneous proliferation of benign-appearing cytophagic histiocytes and lymphocytes often associated with systemic macrophage activation syndrome (MAS). Its pathogenesis is unknown.

\section{Aim}

To report on immunohistochemical findings on skin CHP tissue.

\section{Patients}

A 10-month-old year boy and a 4-month-old-year girl presented with multiple erythematous and indurated noduless on the limbs, and developed high-grade fever and biological features suggestive of MAS several months after the onset of cutaneous disease. Serologic test for EBV was negative and bone marrow examination revealed hemophagocytosis. A homozygous splicing mutation for the UNC13D gene encoding for Munc 13-4 was present in patient 1 , but NK cell cytotoxicity and degranulation assays, and expression of Munc 13-4 protein were normal. No mutation was found in Patient 2. Prednisone alone failed to induce a sustained remission which was obtained by adding cyclosporine $\mathrm{A}$.

\section{Results}

Skin biopsy specimen revealed a lobular panniculitis with areas of necrosis in both patients. The inflammatory infiltrate consisted of lymphocytes and macrophages in dermis and hypodermis, and signs of hemophagocytosis. There were no atypical cells. These findings were consistent with CHP. Immunohistochemical stainings showed

\footnotetext{
* Correspondence: brigitte.bader-meunier@nck.aphp.fr

${ }^{1}$ Department of Pediatrics, Paris, France

Full list of author information is available at the end of the article
}

numerous CD68 macrophages and CD8+lymphocytes, expressing HLA-DR, and a few CD4+ cells. Lymphocytes expressed IFN- $\gamma$ and macrophages TNF- $\alpha$ and IL6. These immunohistochemical features were characteristic of MAS.

\section{Conclusion}

This study provides evidence that CHP may represent MAS in situ in adipose tissue; and emphasized that CHP can precede systemic signs of MAS by several months.

\section{Author details}

${ }^{1}$ Department of Pediatrics, Paris, France. ${ }^{2}$ Department of Pathology, Paris, France. ${ }^{3}$ Department of Pathology, Leuven, Belgium. ${ }^{4}$ INSERM U 768, Paris France. ${ }^{5}$ Department of Pediatrics, Toulouse, France. ${ }^{6}$ Department of Dermatology, Paris, France. ${ }^{7}$ Department of Pediatrics, Leuven, Belgium.

Published: 14 September 2011

doi:10.1186/1546-0096-9-S1-P308

Cite this article as: Bader-Meunier et al:: Cytophagic histiocytic panniculitis: is it a macrophage activation syndrome in situ? Pediatric Rheumatology 2011 9(Suppl 1):P308.

Submit your next manuscript to BioMed Central and take full advantage of:

- Convenient online submission

- Thorough peer review

- No space constraints or color figure charges

- Immediate publication on acceptance

- Inclusion in PubMed, CAS, Scopus and Google Scholar

- Research which is freely available for redistribution
C Biomed Central 